\title{
The Temporal and Spatial Variations in Lake Surface Areas in Xinjiang, China
}

\author{
Yuting Liu ${ }^{1,2}$, Jing Yang ${ }^{1,3, *}$, Yaning Chen ${ }^{1}$, Gonghuan Fang ${ }^{1}$ and Weihong $\mathrm{Li}^{1}$ \\ 1 State Key Laboratory of Desert and Oasis Ecology, Xinjiang Institute of Ecology and Geography, \\ Chinese Academy of Sciences, Urumqi 830011, China; xiaoxiao861211@163.com (Y.L.); \\ chenyn@ms.xjb.ac.cn (Y.C.); fanggh@ms.xjb.ac.cn (G.F.); liwh@ms.xjb.ac.cn (W.L.) \\ 2 University of Chinese Academy of Sciences, Beijing 100049, China \\ 3 National Institute of Water and Atmospheric Research, Christchurch 8011, New Zealand \\ * Correspondence: yangjing@ms.xjb.ac.cn; Tel.: +86-991-782-3171
}

Received: 22 November 2017; Accepted: 30 March 2018; Published: 4 April 2018

\begin{abstract}
In arid areas, lakes play important roles in sustaining the local ecology, mitigating flood hazard, and restricting economic activity of society. In this study, we used multi-temporal satellite data to study annual variations in 16 natural lakes with individual surface areas over $10 \mathrm{~km}^{2}$, categorized into six regions based on their geographical and climatic information and on their relations with climate variables. Results indicated that annual variations in lake surface areas are different across these six regions. The surface area of Kanas Lake has not obviously changed due to its typical U-shape cross section; the areas of Ulungur Lake and Jili Lake increased sharply in the 1980s and then slightly decreased; the areas of Sayram Lake, Ebinur Lake, and Bosten Lake increased and then decreased, with peaks detected in the early 2000s; the areas of Barkol Lake and Toale Culler decreased, while those of the lakes located in the Kunlun Mountains steadily increased. Lake areas also show various relationships with climate variables. There is no obvious relationship between area and climate variables in Kanas Lake due to the specific lake morphology; the areas of most lakes showed positive correlations with annual precipitation (except Sayram Lake). A negative correlation between area and temperature were detected in Ulungur Lake, Jili Lake, Barkol Lake, and Toale Culler, while positive correlations were suggested in Bosten Lake and the lakes in the Kunlun Mountains (e.g., Saligil Kollakan Lake, Aksai Chin Lake, and Urukkule Lake).
\end{abstract}

Keywords: lake area variation; Landsat; climate variable; arid region

\section{Introduction}

In arid areas, lakes play important roles in sustaining local ecology, mitigating flood hazard, and restricting economic activity of society [1-4]. The Xinjiang Uygur Autonomous Region (abbreviated as Xinjiang hereafter) is an arid area in Northwestern China, and there are 137 lakes larger than $1 \mathrm{~km}^{2}$, covering an area of $5072 \mathrm{~km}^{2}$ in Xinjiang according to the Chinese Lake Catalogue [5]. In addition to the environment, lakes also significantly contribute to the local economy development in Xinjiang, e.g., the tourism in Kanas Lake and Tianchi Lake [6,7], salt mining factories in Barkol Lake, and Toale Culler Lake [8,9], and agricultural activities in Ebinur Lake and Bosten Lake [10,11]. Additionally, lakes are very sensitive to climate change [12]. According to [13], for the period of 1961-2008, the average annual temperature increased by $0.30{ }^{\circ} \mathrm{C}$ per decade and the annual mean precipitation increased significantly in Xinjiang. Therefore, it is very important to study their dynamics and how they change with climate variables.

In the literature, there are numerous lake studies in Xinjiang. The traditional way is to set up monitoring sites and measuring lake dynamics (e.g., water level). For instance, in Bosten Lake and 
Sayram Lake, lake level data were used to analyze temporal and spatial variation $[14,15]$. With the advancement of information technology, remote sensing has been used over the past two decades. Compared to traditional methods, remote sensing is less time-consuming, much more cost-effective, and has gained popularity in the study of lakes worldwide. For example, Bao et al. studied the dynamics of Ebinur Lake [16]; Cheng et al. studied the dynamics of Sayram Lake [15]; Chen et al. studied impact of glacier melt on Bosten Lake [17]; Yu et al. studied the impact of human activity on lakes in Northern Xinjiang [18]; Jing et al. studied major driving forces in six lakes in Xinjiang [19]; $\mathrm{Li}$ et al. researched major lake changes in Xinjiang [20]. However, most of these studies have focused either on a specific lake or on lakes in a specific region. There is a need to study the spatio-temporal dynamics and its relationship with climate variability in a holistic way. This will benefit lake management at the provincial level.

In this study, multi-temporal satellite remote sensing data was used to study 16 natural lakes with areas of over $10 \mathrm{~km}^{2}$, which have been subject to six different geographical and climatic circumstances across Xinjiang from 1972 to 2015.

\section{Materials and Methods}

\subsection{Study Area}

Xinjiang, with an area of more than 1.66 million $\mathrm{km}^{2}$, is located in the northwest of China. It is divided by the Tianshan Mountains into two parts: Northern Xinjiang and Southern Xinjiang. The Northern Xinjiang is composed by the Gurbantünggüt Desert and bound by the Altay Mountains in the north. The Southern Xinjiang is dominated by the Taklamakan Desert and bounded by the Kunlun plateau in the south (Figure 1). The annual mean temperature is about $8{ }^{\circ} \mathrm{C}$ and annual precipitation is less than $200 \mathrm{~mm}$ with a strong spatial heterogeneity [21]. Water is generated in the mountains, flows through the oasis, and finally disappears in the desert.

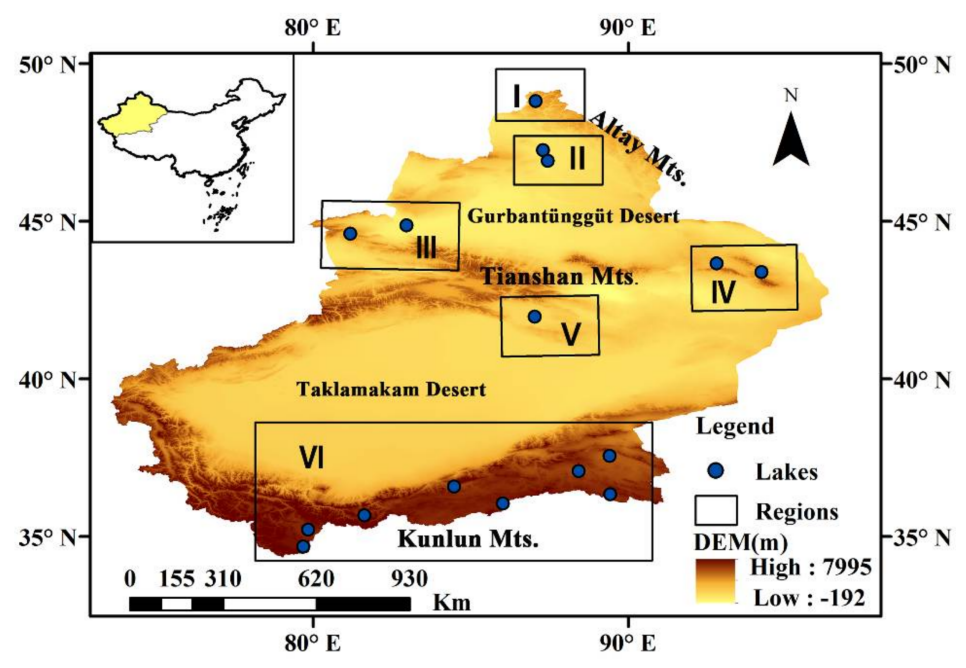

Figure 1. Geographic locations of the studied lakes.

In this study, 16 natural lakes with an individual area larger than $10 \mathrm{~km}^{2}$ were investigated (Figure 1). According to the geographical and climate characteristics of Xinjiang and the distribution of lakes, these lakes were divided into six regions (Table 1). In Region I, one lake (Kanas Lake) in the Altay Mountains is featured with the high mean annual precipitation (up to $567 \mathrm{~mm}$ ) with a high variation (coefficient of variation $24.2 \%$ ). Region II includes two lakes, i.e., Ulungur Lake and Jili Lake, which are near the Gurbantünggüt Desert. Region III includes Sayram Lake and Ebinur Lake, which are located in the Northwestern Tianshan Mountains. In Region IV, two lakes (i.e., Barkol Lake and Toale Culler) located in the northeastern Tianshan Mountains are included. In Region V, lakes 
distributed in the southern Tianshan Mountains and the Bosten Lake are included. In Region VI, eight lakes are distributed at the north slope of the Kunlun plateau with an average elevation of $4953 \mathrm{~m}$. These lakes and regions are shown in Figure 1 and listed in Table 1.

\subsection{Data Collection}

Satellite images were used to extract lake surface areas. Four hundred sixty-four Landsat MSS, TM, ETM+, and OLI images were collected from the U.S. Geological Survey (http://glovis.usgs.gov/). These images have a resolution of $30 \mathrm{~m}$, except for the MSS images, which have a spatial resolution of $60 \mathrm{~m}$. Satellite images that were cloud-free over the studied lakes were selected. To eliminate the effect of seasonal snow cover, selected images were taken between August and October.

The monthly mean temperature and the monthly precipitation with a spatial resolution of $0.5^{\circ} \times 0.5^{\circ}$ from 1971 to 2015 were obtained from the China Meteorological Data Sharing Service System (http:/ /cdc.cma.gov.cn/). These data were used to study the relation between lake areas and climate variables.

Watershed boundaries and stream networks were used to define lake watershed boundaries. These data were obtained from the HydroSHEDS dataset (www.worldwildlife.org/pages/hydrosheds). Together with digital elevation model (DEM) data (lta.cr.usgs.gov/GTOPO30), these watershed boundaries were inspected and modified with the help of Google Earth Geomorphology. Landuse data is provided by the Data Center for Resources and Environmental Sciences, Chinese Academy of Sciences (RESDC) (http:/ / www.resdc.cn). In addition, glacier data, acquired from the second Chinese Glacier Inventory [22], were also used to identify if there was a glacier in the watershed.

\subsection{Extraction of Lake Surface Area from Landsat Image}

MSS, TM, ETM+, and OLI images acquired in the form of digital number (DN) were calibrated to surface reflectance values [23]. Although there are various ways to extract lake surface area (e.g., visual interpretation, water ratio index, and normalized difference moisture index [24]), the normalized difference water index (NDWI) was used to extract lake surface area, as this index is a quick and accurate way to extract water body information [25-28]. NDWI is calculated as

$$
\mathrm{NDWI}=\frac{\rho_{\text {Green }}-\rho_{\text {NIR }}}{\rho_{\text {Green }}+\rho_{\text {NIR }}}
$$

where $\rho_{\text {Green }}$ and $\rho_{\text {NIR }}$ are the reflectances of green and NIR bands, respectively. The NDWI value ranges from -1 to 1 . When applying NDWI, one needs to set the NDWI segmentation thresholds, which are normally between 0 and 0.2 [29,30]. NDWI segmentation threshold was set to 0.2 for salt lakes and 0 for other lakes to distinguish water bodies and vegetation information. Areas with an NDWI greater than 0 or 0.2 were defined as lake area. Finally, all lake areas were visually inspected using a false-color RGB composite image with a combination of Bands 5, 4, and 3 [31,32] and modified based on Google Earth Geomorphology. Figure 2 demonstrates an example of lake area extraction for Sayram Lake and Ebinar Lake in Region III.

\subsection{Statistical Analysis}

A linear-regression analysis was used to study the annual trend of lake area, precipitation, and temperature for each lake region as in Equation (2):

$$
Y=a+b X+\varepsilon
$$

where $Y$ is the dependent variable (i.e., lake area, precipitation, or temperature in the study), and $X$ is the annual time series (e.g., $X=1975,1976, \ldots, 2015)$, coefficients $a$ and $b$ are the intercept and slope of the regression model, and $\varepsilon$ is the error term. Coeffcient $b$ is used to identify the annual change of dependent variable $Y$. 
Correlation coefficient was used to study the relationship between climate variables and lake area at each region as in Equation (3):

$$
r=\frac{\sum_{i=1}^{n}\left(x_{i}-\bar{x}\right)\left(y_{i}-\bar{y}\right)}{\sqrt{\sum_{i=1}^{n}\left(x_{i}-\bar{x}\right)^{2} \sum_{i=1}^{n}\left(y_{i}-\bar{y}\right)^{2}}}
$$

where $y_{i}(i=1, \ldots, n)$ is a time series of lake area with average $\bar{y}$, and $x_{i}(i=1, \ldots, n)$ is a time series of climate variable with average $\bar{x}$. These climate variables include annual precipitation (AP, $\mathrm{mm})$, annual mean temperature $\left(\mathrm{AMT},{ }^{\circ} \mathrm{C}\right)$, previous one-month, two-month, and three-month precipitations of the lake area (P1, P2, and P3), temperature from March to May (T3_5), and temperature from June to August (T6_8). P1, P2, and P3 are used to study how fast the lake area responds to precipitation in summer, and T3_5 and T6_8 are used to indicate the effects of snowmelt and glacial melt on lake area.
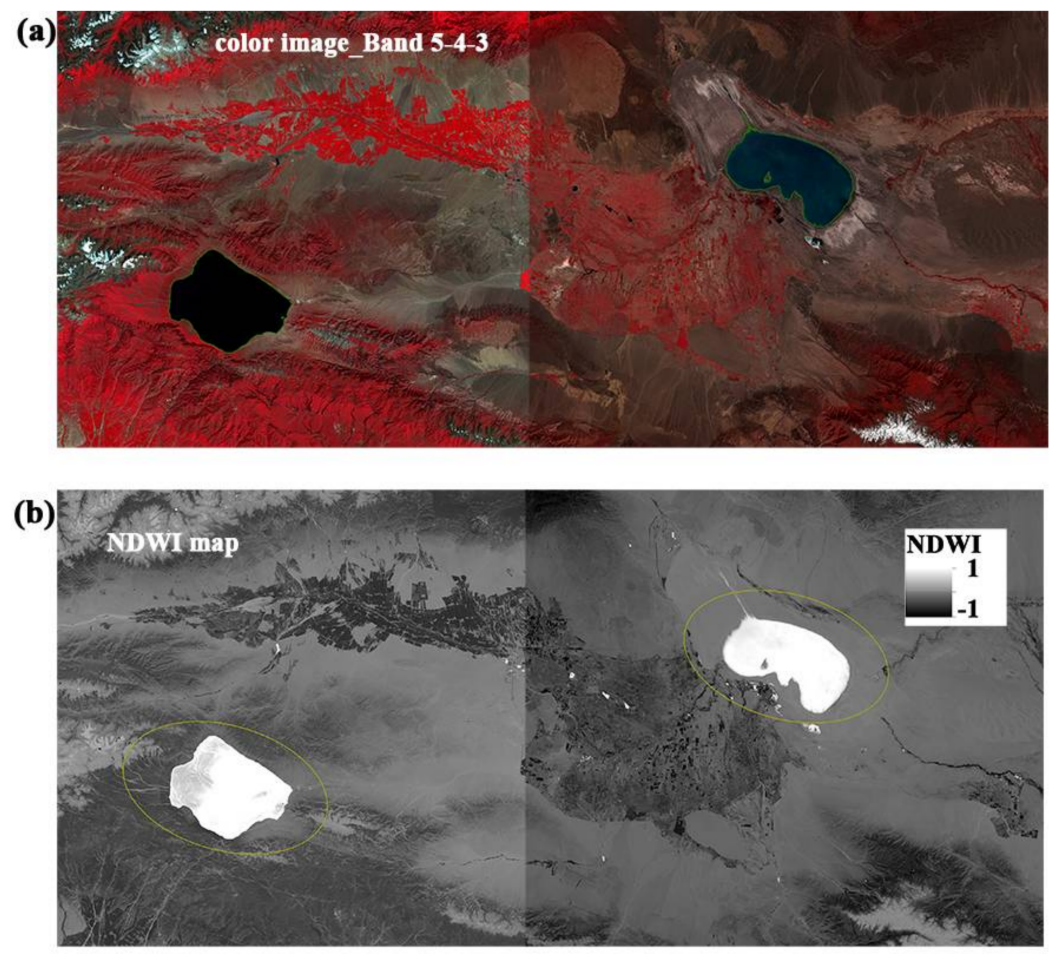

(c)
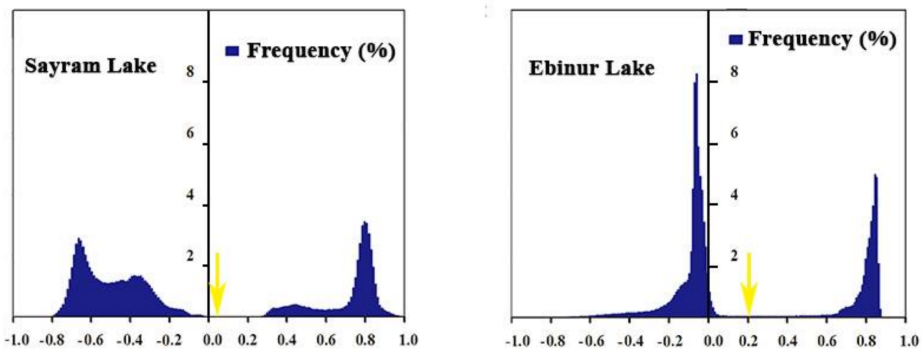

Figure 2. Representative lake water extent mapping based on NDWI: (a) A false-color RGB composition of Bands 5, 4, and 3; (b) NDWI map; (c) Distribution of spectral frequency.

\section{Results and Discussion}

\subsection{Spatial and Temporal Variability of Temperature and Precipitation}

Figure 3 shows mean annual precipitation (AP) and mean annual temperature (AMT) for the period of 1971-2015. Both mean annual precipitation and mean annual temperature exhibit strong 
spatial variation. AMT ranges from -6.6 to $3.3^{\circ} \mathrm{C}$ with a mean $-1.0^{\circ} \mathrm{C}$ and AP from 157 to $567 \mathrm{~mm}$ with a mean of $303 \mathrm{~mm}$. Precipitation decreases from Regions I to VI, while temperature decreases from the Tianshan Mountain regions (Regions III, IV, and V) to the South and the North (Region I).

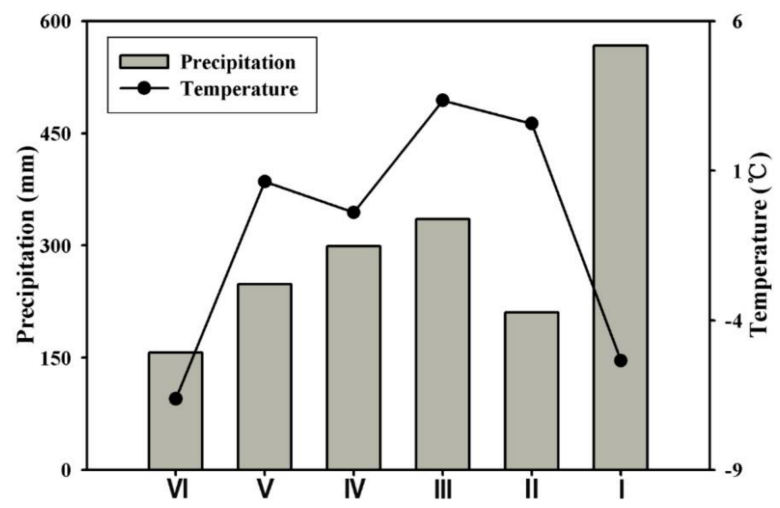

Figure 3. Mean annual precipitation $(\mathrm{AP}, \mathrm{mm})$ and annual mean temperature $\left(\mathrm{AMT},{ }^{\circ} \mathrm{C}\right)$ of the six regions for the period of 1971-2015.

Figure 4 shows the temporal variations in AP and AMT in each region. For all regions, AP slightly increased (i.e., all coefficients are positive) although it is significant $(p<0.05)$ only in regions II $(p=0.022)$ and $\mathrm{V}(p=0.0153)$. On the contrary, AMT shows a significant increase in all regions (i.e., $p<0.05)$. In the six regions, the temperature increasing rate ranges from $0.0192{ }^{\circ} \mathrm{C} / \mathrm{a}(p<0.05)$ to $0.0461{ }^{\circ} \mathrm{C} / \mathrm{a}(p<0.0001)$. The highest increase rate was found in Region IV, followed by Regions II, III, and VI, where these values approaching $0.04{ }^{\circ} \mathrm{C} / \mathrm{a}(p<0.0001)$, and the lowest increase rate was shown in Region I.
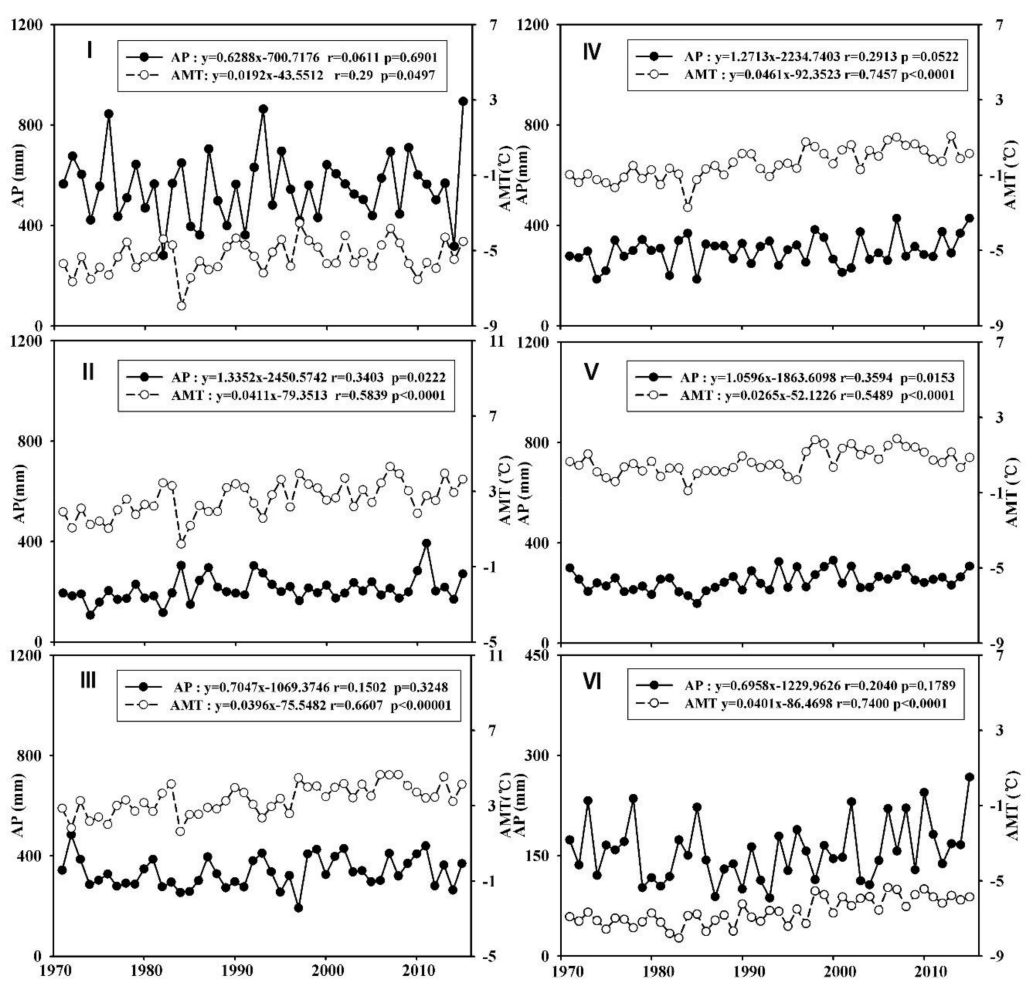

Figure 4. Interannual variations in annual precipitation (AP, $\mathrm{mm}$ ) and annual mean temperature $\left(\mathrm{AMT},{ }^{\circ} \mathrm{C}\right)$ at each region from 1971 to 2015. 


\subsection{Variations in Lake Area and Landuse in Each Region}

Table 1 and Figure 5 shows lake area change from the 1970s to 2015 in each region. The total lake surface area increased from $4594 \mathrm{~km}^{2}$ in the 1970 s to $5222 \mathrm{~km}^{2}$ in 2015 with an expansion of $13.7 \%$. However, different regions experience different changes. Region I does not show a significant change, with a mean lake area of $43.76 \mathrm{~km}^{2}$ and a standard deviation of $0.2 \mathrm{~km}^{2}$. For Region II, there was a sharp increase in the 1980s from $941.32 \mathrm{~km}^{2}$ to $1049.62 \mathrm{~km}^{2}$, which was followed by a slight decrease. For Region III, there was a significant increase from 1999 to 2003, followed by a significant decrease to 2015. For Region IV, lake area decreased. Region V had a similar pattern as Region III, and its area peaked in 1999 2002. For Region VI, there is a steady increase trend in the lake area with a rate of $27.78 \mathrm{~km}^{2} /$ a with a $p$ value smaller than 0.0001 from the 1970s to 2015 .

Figure 6a shows the landuse map in Xinjiang in 2015. There were no significant visual changes from 1980 to 2015. Other plots show the percentages of each landuse category in each region from 1980 to 2015. Generally, there have been no significant changes in landuse in each region. Except Region I, Sayram Lake in Region III, and Region VI, there is a certain amount of cultivated land in each region. Although areas of this cultivated land are small (around or over 5\%), its influence on lake area is significant, as cultivated land is distributed around lakes and acts either to intercept riverflow before it flows to the lake or to divert lake water for human uses (irrigation, industry, and domestic use).

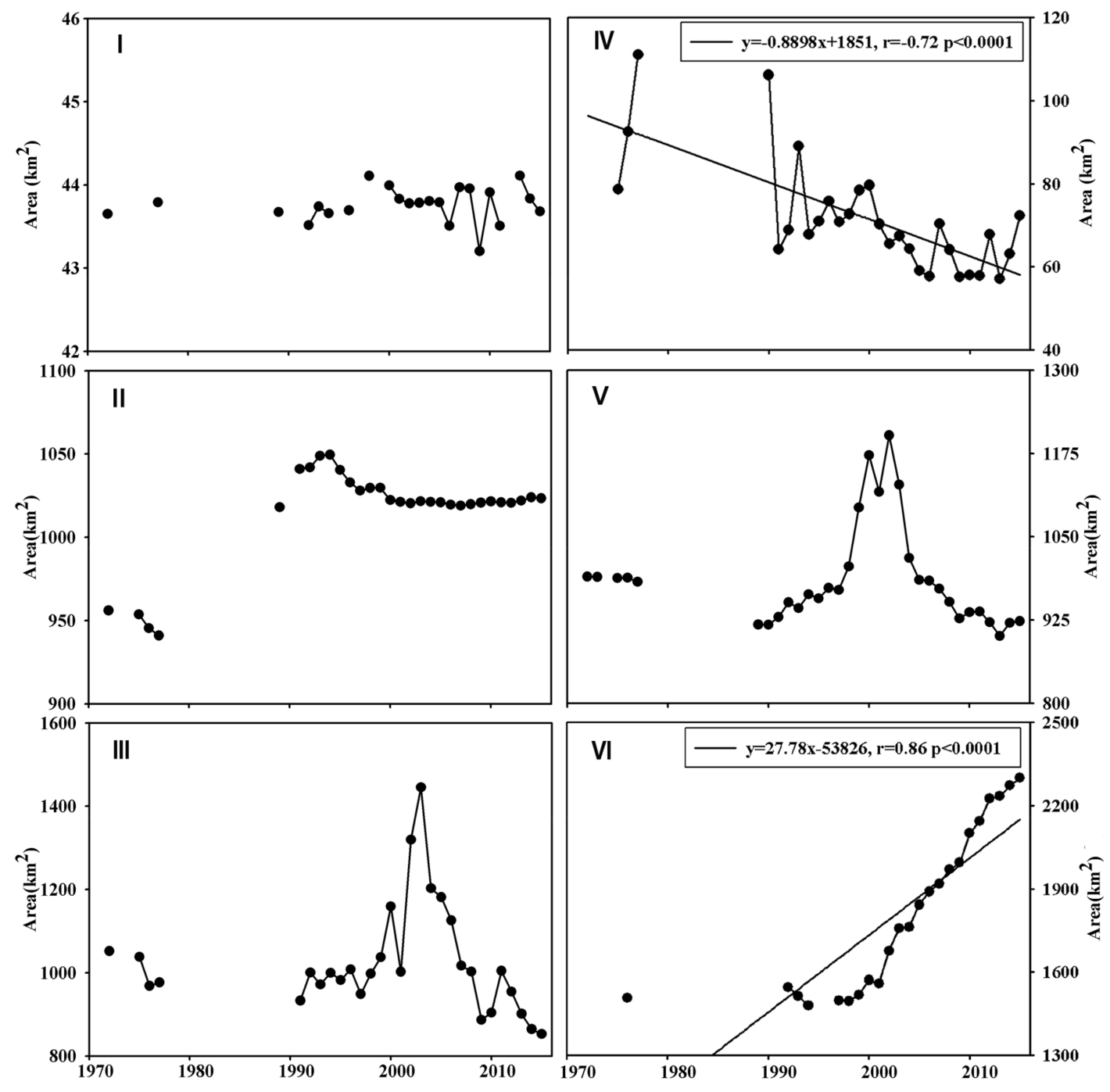

Figure 5. Inter-annual variations in lake areas in six regions from 1972 to 2015. 
Table 1. Basic information on lakes in the six regions and the changing rates of lake areas in the past 45 years.

\begin{tabular}{|c|c|c|c|c|c|c|c|}
\hline \multirow{2}{*}{ Region } & \multirow{2}{*}{ Lakes } & \multirow{2}{*}{$\begin{array}{l}\text { Area in the } \\
1970 \mathrm{~s}\left(\mathrm{~km}^{2}\right)\end{array}$} & \multicolumn{4}{|c|}{ Change Rate (\%) } & \multirow{2}{*}{$\begin{array}{c}\text { Area in } 2015 \\
\left(\mathrm{~km}^{2}\right)\end{array}$} \\
\hline & & & 1970s-1993 & 1993-2004 & 2004-2015 & 1970s-2015 & \\
\hline I & Kanas Lake & 43.72 & 0.04 & 0.15 & -0.29 & -0.09 & 43.68 \\
\hline \multirow{2}{*}{ II } & Ulungur Lake & 778.76 & 12.32 & -2.63 & 0.21 & 9.60 & 853.50 \\
\hline & Jili Lake & 162.57 & 7.18 & -2.66 & 0.17 & 4.51 & 169.90 \\
\hline \multirow{2}{*}{ III } & Sayram Lake & 455.79 & 0.29 & 0.54 & 0.30 & 1.13 & 460.96 \\
\hline & Ebinur Lake & 554.01 & -7.44 & 44.66 & -47.14 & -29.22 & 392.12 \\
\hline \multirow{2}{*}{ IV } & Barkol Lake, & 74.18 & -12.02 & -37.78 & 22.71 & -32.82 & 49.83 \\
\hline & Toale Culler & 21.39 & 10.94 & -0.13 & -4.99 & 5.26 & 22.51 \\
\hline V & Bosten Lake & 987.70 & -5.65 & 9.32 & -9.36 & -6.51 & 923.41 \\
\hline \multirow{8}{*}{ VI } & Saligil Kollakan & 47.34 & 4.36 & 38.18 & -8.78 & 31.54 & 62.27 \\
\hline & Aksai Chin Lake & 168.99 & -0.93 & 11.18 & 39.94 & 54.14 & 260.48 \\
\hline & Urukkule Lake & 14.98 & 3.31 & 4.21 & 5.94 & 14.05 & 17.09 \\
\hline & Tashkule Lake & 11.11 & -4.57 & 9.70 & 158.49 & 170.62 & 30.05 \\
\hline & Changhong Lake & 17.77 & -19.09 & 112.48 & 81.86 & 212.64 & 55.56 \\
\hline & Whale Lake & 276.53 & -7.01 & 12.01 & 17.40 & 22.28 & 338.16 \\
\hline & Aqqikkol Lake & 359.66 & 0.65 & 16.31 & 27.97 & 49.81 & 538.81 \\
\hline & Ayakekum Lake & 615.44 & 3.63 & 15.92 & 34.41 & 61.47 & 993.73 \\
\hline
\end{tabular}

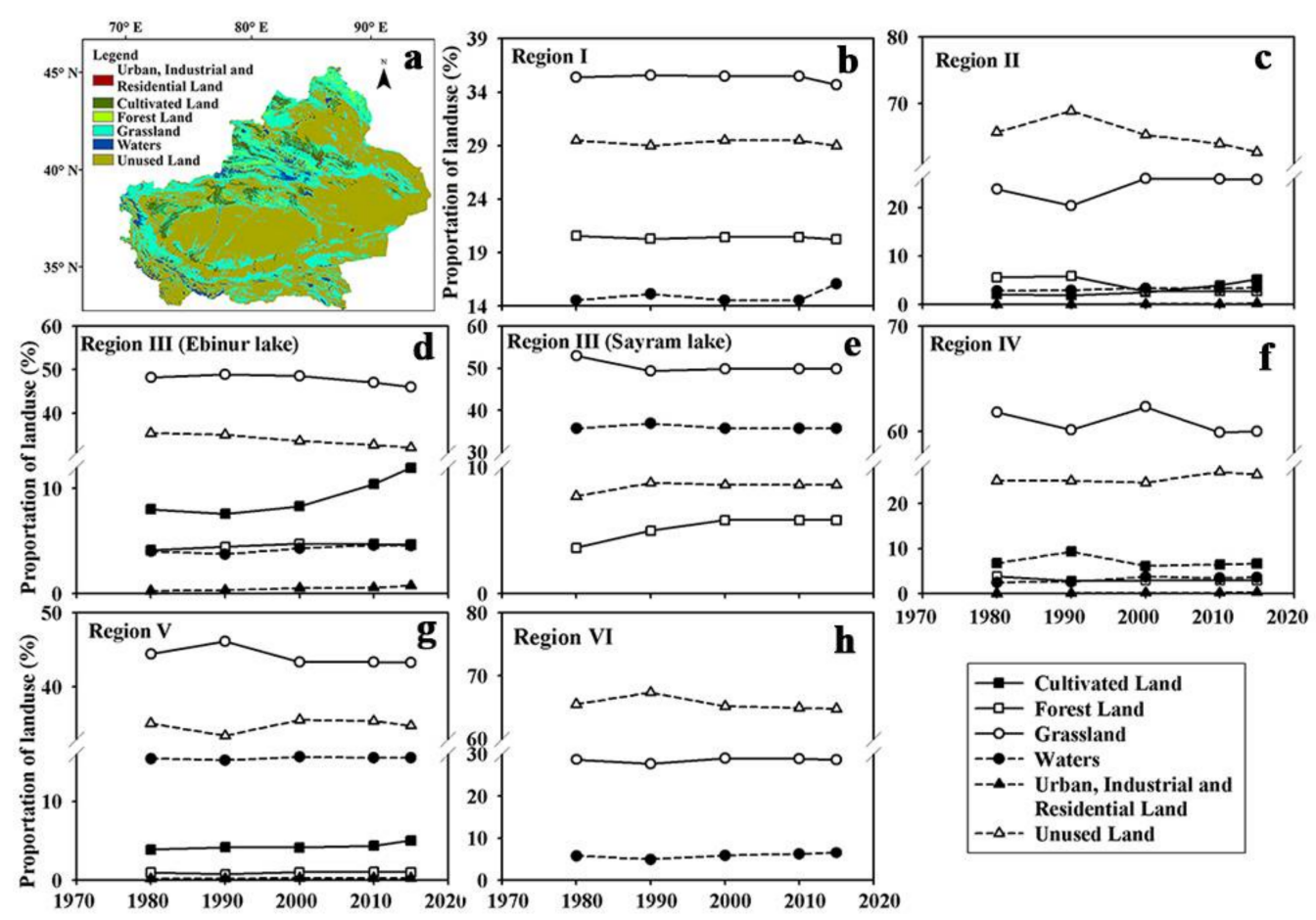

Figure 6. Landuse map of Xinjiang in 2015 (a) and variations in landuse during 1980 to 2015 in each region $(\mathbf{b}-\mathbf{h})$.

\subsection{Relationships between the Lake Area and Climate Variables}

Table 2 lists correlations between lake area and climate variables in each region. Except for those in Region III, lakes show similar correlations with these climate variables within the same region. It is worth noting that the lake in Region I (Kanas Lake) is peculiar because the lake area does not change significantly, and this caused a large amount of uncertainty when the satellite images were processed. This region is not discussed here, but will be discussed in Section 4. For all regions (except Sayram Lake in Region III, which has no correlation with precipitation), lake area has a positive correlation 
with $\mathrm{AP}$, and these correlations are significant (except in Region IV), especially in Regions III (i.e., Ebinur Lake) and VI (i.e., correlation coefficients are 0.44 and 0.58 at a significance level of 0.05). These indicated a relatively strong (compared to other regions) positive impact of precipitation on lake area. Columns P1, P2, and P3 show correlations between lake area and previous one-month, two-month, and three-month precipitations. For P1, lake area has a significant correlation only in Region V, while there is no effect in Regions II and VI. For P2, lake area has a significant correlation only in Region VI, while correlations are not significant in other regions. For P3, correlations in Regions II, V, and VI are significant (especially Region II-0.55). Correlations with P1, P2, and P3 indicates a lagged lake inflow from rainfall.

For AMT, lake area is negatively correlated with AMT in Regions II and IV and has a significant positive correlation in Regions V and VI and in Sayram Lake in Region III. There is no correlation for Ebinur Lake in Region III. Except in Region V, lake area has a similar correlation with T3_5 as with AMT. For T6_8, lake area has significant negative correlations with T6_8 in Regions II and IV, while it has positive correlations in Regions I (0.35) and VI (0.20).

Table 2. Correlations between lake area and climate variables in each region ${ }^{*}$ and ${ }^{* *}$ indicate the significance level of 0.10 and 0.05 , respectively).

\begin{tabular}{cccccccc}
\hline Region & AP & P1 & P2 & P3 & AMT & T3_5 & T6_8 \\
\hline I & 0.26 & 0.03 & 0.26 & 0.24 & 0.18 & 0.14 & -0.02 \\
II & $0.38^{*}$ & -0.13 & 0.21 & $0.55^{* *}$ & -0.28 & -0.25 & $-0.36^{*}$ \\
III (Sayram Lake) & -0.02 & 0.01 & -0.08 & -0.09 & $0.49^{* *}$ & $0.56^{* *}$ & $0.47^{* *}$ \\
III (Ebinur Lake) & $0.44^{*}$ & 0.31 & 0.29 & 0.13 & -0.02 & 0.01 & 0.16 \\
IV & 0.32 & 0.22 & 0.26 & 0.25 & -0.27 & -0.27 & $-0.48^{* *}$ \\
V & $0.34^{*}$ & $0.39 *$ & 0.32 & $0.38^{*}$ & $0.45^{*}$ & -0.03 & $0.35^{*}$ \\
VI & $0.58^{* *}$ & 0.09 & $0.45^{*}$ & $0.44^{*}$ & $0.36^{*}$ & $0.40^{*}$ & 0.20 \\
\hline
\end{tabular}

\section{Discussion}

As mentioned earlier, in Region I, lake area does not change too much. According to Feng [33], cross sections along the longitudinal direction are in U-shape forms through historical glacier erosion (Figure 7). Figure 7 also shows the relations of lake area and volume with water level. At a lake area of $43 \mathrm{~km}^{2}$, the slope of the lake area in Figure 7 is $0.1656 \mathrm{~km}^{2} / \mathrm{m}$, while the slope of lake volume is $0.326 \times 10^{8} \mathrm{~m}^{3} / \mathrm{m}$. This means that a $1 \mathrm{~m}$ increase of water level led to a $0.1656 \mathrm{~km}^{2}$ increase in lake area, and a $0.326 \times 10^{8} \mathrm{~m}^{3}$ increase in volume. Therefore, it is very hard to study the impact of climate change (or variation) on this lake with this satellite data. The result listed in Table 2 are rather heavily impacted by errors in these satellite data.

Sayram Lake and Ebinur Lake in Region III behave differently with respective to their correlations with precipitation and temperature. Sayram Lake has a strong positive correlation with temperature (AP, T3_5, and T6_8) but no correlation with precipitation, and this indicates snowmelt and glacier melt causes lake area fluctuation. On the contrary, Ebinur Lake has a strong positive correlation with precipitation, but no correlation with temperature. Sayram Lake catchment is a closed catchment surrounded by mountains with little human activity, while Ebinur Lake catchment has been heavily influenced by human activity such as population growth and increased cultivated lands, as was demonstrated in Figure 6 [16]. Human intervention has complicated the relationship between lake area and temperature.

Except for Regions I and III, all regions show a positive correlation with AP. To some degree, these values indicate the extent to which human intervention is involved. For example, Region IV has a low correlation, which suggests strong human activities (e.g., salt extraction) in this region [8,9] as indicated in Figure 6, whereas Region VI has a high correlation and there is less human activity compared to Region IV. The correlation with P1, P2, and P3 indicates if there is a lagged response of lake area to rainfall. As all lake area data were collected in August and September, and given that most 
rain falls in June, July, and August, if the correlation with P1 is high, then the reaction is very high. However, strong reaction of lake area to $\mathrm{P} 1$ will not necessarily indicate a high correlation between them, as there might be human intervention.

Temperature can have two effects on lake inflow, one is to reduce it through evapotranspiration and the other is to increase it by causing snowmelt and/or glacier melt if any. In our study, Regions V and VI have high positive correlations with AMT, which indicates that the effect of snowmelt and/or glacier melt is larger than evapotranspiration. This is confirmed by its correlation with snowmelt factor T3_5 (only for Region VI) and glacier melt factor T6_8. It is worth noting that, in Region V, the correlation with T3_5 is low because of river water use for plant seeding and growing [34,35]. On the contrary, Regions II and IV have negative correlations with AMT, which means evapotranspiration dominates. This is confirmed by its negative correlation with temperature in spring and summer (T3_5 and T6_8).
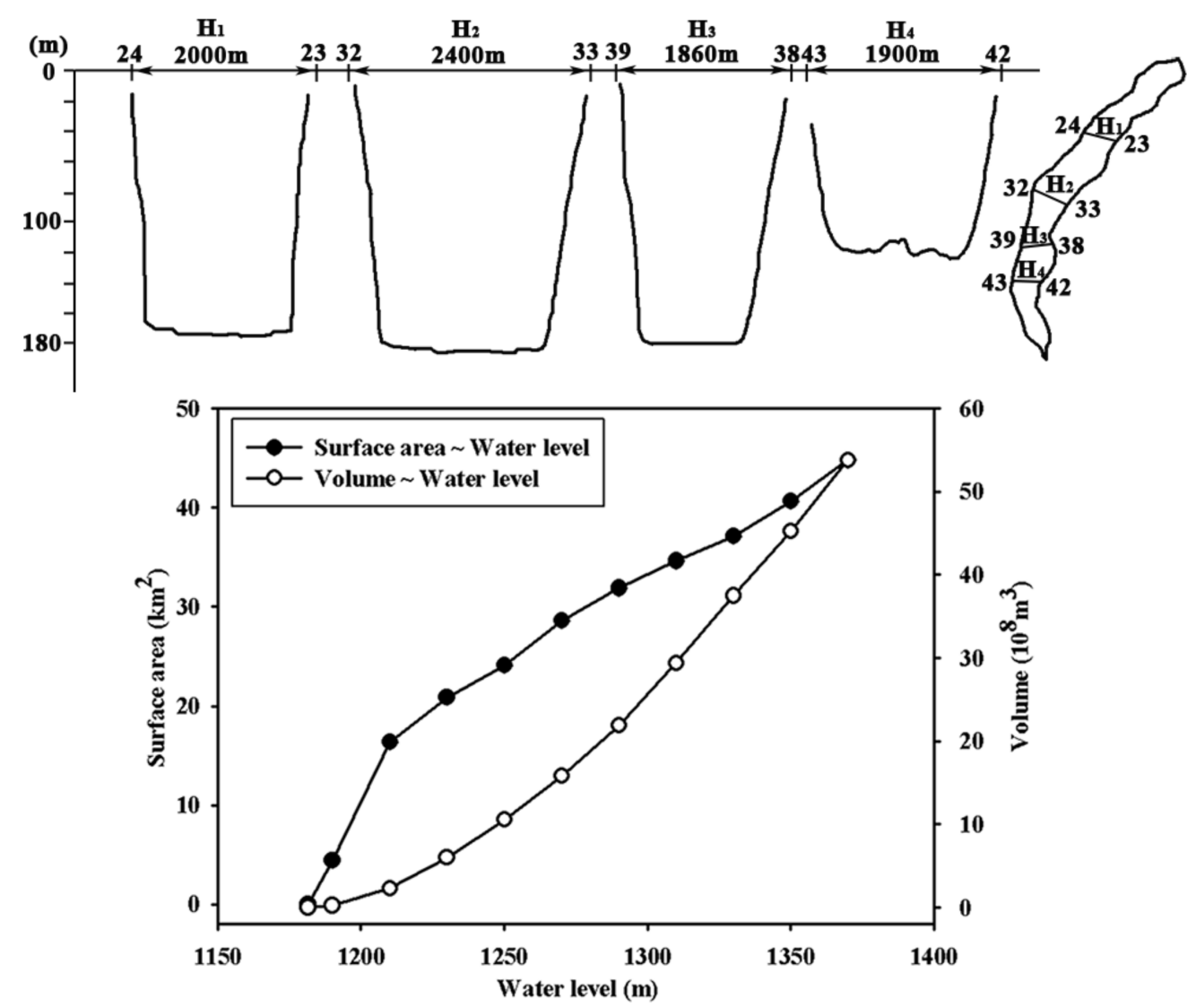

Figure 7. Typical cross section area and relations between water level, surface area, and the volume of Kanas Lake in Region I. (Adapted from Feng et al [33])

\section{Conclusions}

In this study, we used multi-temporal satellite data to study annual variations in 16 natural lakes with individual surface areas over $10 \mathrm{~km}^{2}$, which were categorized into six regions based on their geographical and climate information and on their relations with climate variables. We conclude the following:

(1) The annual variations in lake surface areas are different across six different regions. The surface area of Kanas Lake (Region I) did not show any obvious change during 1972 2015, due to its U-shape cross-sectional profile, which means that the water level is a better variable than lake area to study the relationship between lake variation and climate factors; lake area in Region II largely 
increased in the 1980s and then slightly decreased; lake area in Regions III and V increased and then decreased with the peaks in the early 2000s; lake area decreased in Region IV but increased in Region VI.

(2) Lake areas also show different relationships with climate variables across six different regions. The surface area of Kanas Lake (Region I) did not show any obvious relationship with climate variables; lake area in the other regions of all lakes (except Sayram Lake in Region III) was positively correlated with annual precipitation (AP), and this was significant in Ebinur Lake in Regions III and IV; lake area in Regions II and IV was negatively correlated with annual mean temperature (AMT), and evapotranspiration had a great impact on lake area; lake area in Regions V and VI was positively correlated with annual mean temperature (AMT), and snowmelt and glacier melt had a great impact on lake area. However, in Region V, the effect of snowmelt was diminished by human activity.

The dynamics of lake area is very complicated and influenced by its geographical characteristics, climate variables, glacier coverage, and human activity. However, this study only touches on geological characteristics, climate variables, and glacier coverage. As human interaction with the local water resources in Xinjiang has increased, lake area, as a result, has developed substantially. This needs to be investigated next.

Acknowledgments: This research was supported by the National Natural Science Foundation of China $(41630859,71503248)$. We would like to acknowledge two anonymous reviewers for their constructive comments, which significantly improved this manuscript.

Author Contributions: Yuting Liu analyzed the data and wrote the first draft. Jing Yang proposed and improved the main structure of this manuscript. Gonghuan Fang did the watershed delineation and Yaning Chen and Weihong Li provided helpful suggestions to improve this paper. All authors contributed to the final manuscript.

Conflicts of Interest: The authors declare no conflict of interest.

\section{References}

1. An, C.B.; Feng, Z.D.; Barton, L. Dry or humid? Mid-Holocene humidity changes in arid and semi-arid China. Quat. Sci. Rev. 2006, 25, 351-361. [CrossRef]

2. Wang, X.; Shiyin, L.; Wanqin, G.; Junli, X. Assessment and simulation of glacier lake outburst floods for Longbasaba and Pida lakes, China. Mt. Res. Dev. 2008, 28, 310-317.

3. Fang, C.L.; Bao, C.; Huang, J.C. Management implications to water resources constraint force on socio-economic system in rapid urbanization: A case study of the Hexi Corridor, NW China. Water Resour. Manag. 2007, 21, 1613-1633. [CrossRef]

4. Zhang, J.; Xu, J.; Zhang, Y.; Wang, M.; Cheng, Z. Water resources utilization and eco-environmental safety in Northwest China. J. Geogr. Sci. 2006, 16, 277-285. [CrossRef]

5. Wu, J.; Ma, L. Lake evolution and climatic and hydrological changes in arid zone of Xinjiang. Mar. Geol. Quat. Geol. 2011, 31, 135-143. (In Chinese)

6. Tang, G.; Zheng, W.; Wang, X.; Zhu, Y. Evaluation and development of folklore tourism resources in Kanas. Grassl. Turf 2017, 37, 98-103. (In Chinese)

7. Toops, S. Tourism in Xinjiang, China. J. Cult. Geogr. 2009, 12, 19-34. [CrossRef]

8. Wang, S.M.; Dou, H.S. Chinese Lake Catalogue; Science Press: Beijing, China, 1998. (In Chinese)

9. Zheng, S.L.; Luo, L.P. Variation of water quality in Balikun lake in the last 18 years and water resource protection strategies. Environ. Sci. Technol. 2011, 34, 85-88.

10. Ma, L.; Wu, J.; Abuduwaili, J.; Liu, W. Geochemical responses to anthropogenic and natural influences in Ebinur Lake sediments of arid Northwest China. PLoS ONE 2016, 11, e0155819. [CrossRef] [PubMed]

11. Guo, M.; Wu, W.; Zhou, X.; Chen, Y.; Li, J. Investigation of the dramatic changes in lake level of the Bosten Lake in Northwestern China. Theor. Appl. Climatol. 2015, 119, 341-351. [CrossRef]

12. Liu, H.; Yin, Y.; Piao, S.; Zhao, F.; Engels, M.; Ciais, P. Disappearing lakes in semiarid northern China: Drivers and environmental impact. Environ. Sci. Technol. 2013, 47, 12107-12114. [CrossRef] [PubMed] 
13. Zhang, Y.; Wei, W.; Jiang, F.; Liu, M.; Wang, W.; Bai, L.; Li, K. Brief communication “Assessment of change in temperature and precipitation over Xinjiang, China". Nat. Hazards Earth Syst. Sci. Discuss. 2012, 2, 1289-1291. [CrossRef]

14. Zhou, H.; Chen, Y.; Perry, L.; Li, W. Implications of climate change for water management of an arid inland lake in Northwest China. Lake Reserv. Manag. 2015, 31, 202-213. [CrossRef]

15. Cheng, W.; Wang, N.; Zhao, S.; Fang, Y.; Zhao, M. Growth of the Sayram Lake and retreat of its water-supplying glaciers in the Tianshan Mountains from 1972 to 2011. J. Arid Land 2016, 8, 13-22. [CrossRef]

16. Bao, A.; Mu, G.; Zhang, Y.; Feng, X.; Chang, C.; Yin, X. Estimation of the rational water area for controlling wind erosion in the dried-up basin of the Ebinur Lake and its effect detection. Chin. Sci. Bull. 2006, 51, 68-74. [CrossRef]

17. Chen, X.; Wu, J.; Hu, Q. Simulation of climate change impacts on streamflow in the Bosten Lake basin using an artificial neural network model. J. Hydrol. Eng. 2008, 13, 180-183. [CrossRef]

18. Yu, S.; Sun, L.; Sun, Z.; Wu, M. Water body extraction and change analysis based on landsat image in Xinjiang coal-mining regions. In Proceedings of the Geoscience and Remote Sensing Symposium, Beijing, China, 10-15 July 2016.

19. Jing, Y.; Zhang, F.; Wang, X. Monitoring dynamics and driving forces of lake changes in different seasons in Xinjiang using multi-source remote sensing. Eur. J. Remote Sens. 2018, 51, 150-165. [CrossRef]

20. Li, Q.; Lu, L.; Wang, C.; Li, Y.; Sui, Y.; Guo, H. MODIS-derived spatiotemporal changes of major lake surface areas in arid Xinjiang, China, 2000-2014. Water 2015, 7, 5731-5751. [CrossRef]

21. Xu, Y.; Yang, J.; Chen, Y. NDVI-based vegetation responses to climate change in an arid area of China. Theor. Appl. Climatol. 2015, 126, 213-222. [CrossRef]

22. Liu, S.; Yao, X.J.; Guo, W.Q.; Xu, J.L.; Shangguan, D.H.; Wei, J.F.; Bao, W.J.; Wu, L.Z. The contemporary glaciers in China based on the second Chinese glacier inventory. Acta Geogr. Sin. 2015, 70, 3-16. (In Chinese)

23. Wang, F.; Han, L.; Kung, H.T.; Van Arsdale, R.B. Applications of Landsat-5 TM imagery in assessing and mapping water quality in Reelfoot lake, Tennessee. Int. J. Remote Sens. 2006, 27, 5269-5283. [CrossRef]

24. Rokni, K.; Ahmad, A.; Selamat, A.; Hazini, S. Water feature extraction and change detection using multitemporal Landsat imagery. Remote Sens. 2014, 6, 4173-4189. [CrossRef]

25. Tao, S.; Fang, J.; Zhao, X.; Zhao, S.; Shen, H.; Hu, H.; Tang, Z.; Wang, Z.; Guo, Q. Rapid loss of lakes on the Mongolian Plateau. Proc. Natl. Acad. Sci. USA 2015, 112, 2281-2286. [CrossRef] [PubMed]

26. Mcfeeters, S.K. The use of the Normalized Difference Water Index (NDWI) in the delineation of open water features. Int. J. Remote Sens. 1996, 17, 1425-1432. [CrossRef]

27. $\mathrm{Xu}, \mathrm{H}$. Modification of normalised difference water index (NDWI) to enhance open water features in remotely sensed imagery. Int. J. Remote Sens. 2006, 27, 3025-3033. [CrossRef]

28. Rogers, A.; Kearney, M. Reducing signature variability in unmixing coastal marsh Thematic Mapper scenes using spectral indices. Int. J. Remote Sens. 2004, 25, 2317-2335. [CrossRef]

29. Song, C.; Sheng, Y. Contrasting evolution patterns between glacier-fed and non-glacier-fed lakes in the Tanggula Mountains and climate cause analysis. Clim. Chang. 2016, 135, 493-507. [CrossRef]

30. Du, Z.; Li, W.; Zhou, D.; Tian, L.; Ling, F.; Wang, H.; Gui, Y.; Sun, B. Analysis of Landsat-8 OLI imagery for land surface water mapping. Remote Sens. Lett. 2014, 5, 672-681. [CrossRef]

31. Castañeda, C.; Herrero, J.; Casterad, M.A. Landsat monitoring of playa-lakes in the Spanish Monegros desert. J. Arid Environ. 2005, 63, 497-516. [CrossRef]

32. Scepan, J. Thematic validation of high-resolution global land-cover data sets. Photogramm. Eng. Remote Sens. 1999, 65, 1051-1060.

33. Feng, M. Landform and origin of Hanasi lake, Altay Mountains. J. Glaciol. Geocryol. 1993, 15, 559-565. (In Chinese)

34. Ma, L.; Zhao, J.; Zhang, H.; Fan, J.; Guo, X. Impact of glacier and snow melting on Bosten Lake under climate change. Arid Land Geogr. 2010, 33, 210-216. (In Chinese)

35. Ghalip, I.; 'Yimit, H.; Eziz, M.; Rusuli, Y. The driving forces of the Bosten Lake water level variations in 1958-2012. J. Desert Res. 2015, 35, 240-247. (In Chinese)

(C) 2018 by the authors. Licensee MDPI, Basel, Switzerland. This article is an open access article distributed under the terms and conditions of the Creative Commons Attribution (CC BY) license (http:/ / creativecommons.org/licenses/by/4.0/). 